\title{
Qualitative Analysis of Drinking Water for Pathogenic Bacteria of District Swabi, Pakistan
}

\author{
Qureshi AW ${ }^{1 *}$ and Aiman $0^{2}$ \\ ${ }^{1}$ Department of Zoology, GC Women University Sialkot, Pakistan \\ ${ }^{2}$ Department of Zoology, Abdul Wali Khan University Mardan, Pakistan
}

*Corresponding author: Asma Waheed Qureshi, Department of Zoology, GC Women University Sialkot, Pakistan,Email: asmawqureshi@yahoo.com

\section{Research Article \\ Volume 2 Issue 2}

Received Date: March 18, 2019

Published Date: April 24, 2019

DOI: $10.23880 /$ izab-16000144

\section{Abstract}

This research work presents a study on drinking water quality in District Swabi, Khyber Pakhtunkhwa Pakistan, which involved bacteriological analysis of drinking water for the presence of some pathogenic bacteria from different drinking water sources. Total 103 water samples were analyzed in which 95 (92.23\%) samples were contaminated with pathogenic bacteria. The contamination was highest for Staphylococcus aureus (88.34\%), followed by Salmonella $s p$. (68.9\%) and least contamination was recorded for Pseudomonas aeruginosa (24.27\%). Out of 99 bore water samples, over all contamination was $91.9 \%$ and $100 \%$ for well water. It is concluded that the drinking water of Swabi is contaminated with these pathogenic bacteria and is not safe for drinking purposes. Based on the results it is suggested that authorities should show responsiveness to supply safe water and suitable sanitary facilities to avoid epidemics of infectious diseases in future.

Keywords: Drinking Water; Quality Analysis; Pseudomonas; Salmonella

\section{Introduction}

Water is an important element of life. Without it, life would not have existed on earth. Drinking water from different reservoirs should be free from contamination with waterborne pathogens including bacteria, fungi, viruses and parasites. These pathogenic microbes can exist in surface and ground water sources and can cause serious illnesses, in humans if not treated properly. Water quality is important for the health, social and economic welfare of humans $[1,2]$.

Contaminated water is a worldwide public health danger that places people at risk of diarrheal and other disease as well as chemical intoxication [3]. In term of human health the most dangerous water pollutants are pathogenic microorganism [4]. According to the WHO, the death from water related illnesses surpasses 5 million people per year. Out of these, more than $50 \%$ are microbial intestinal infections [5].

At present, the threat of water borne illnesses and epidemics still rumbles great on the skylines of developing countries. Contaminated water is the perpetrator in such cases [6]. Half of the people of developing world are victim of water associated illnesses throughout the year and 3.4 million individuals pass away each year as a result of intake of fecally polluted water, among these the majority is of infants and children [7]. An estimated 5 million children in the developing countries die due to poor water quality [8]. The fast increase in population has further intensified the problem which results in poor water-quality management [9]. Inadequate water supply and sanitation is responsible for infections 
or diseases for nearly half of all people in developing countries [10]. The developed countries have adopted strategies of checking the quality of drinking water owing to its significance but in developing countries numerous outbreaks of water borne illnesses still occur around the year $[11,12]$.

Pakistan, being a developing country, is also going through the problem of drinking water contamination and safe water is available only to $40-60 \%$ of its whole inhabitants [13]. About 30\% of the patients approaching to hospitals and $40 \%$ of all the mortalities taking place in Pakistan have contaminated drinking water as their cause.

Drinking water quality checking and monitoring programs in the country are lacking. Also, the public awareness of the issue of water quality is miserably low [14]. Drinking water treatment is hardly done before consumption in Pakistan and no such international standards are used for drinking water. There is no proper water supply system to $70 \%$ population of Pakistan living in rural areas. Bacterial contamination of drinking water is one of the gravest problems all over the country [15]. The borehole water pollution occurs through a lot of domestic sewage and animal manure particularly if there is a hole in a layer of soil. The wastes and sewage when dumped near the boreholes may move with rain water and seep right into the boreholes or may be transported along the well-wall $[16,17]$.

There is no study conducted in district Swabi to determine the level of pathogenic bacterial contamination of drinking water sources. Therefore, this study is designed to determine the level of contamination of different drinking water sources in District Swabi.

\section{Materials and Methods}

\section{Sample Collection}

A total of 103 water samples were collected from different areas of district Swabi including Adina, Asmaila, Kalo Khan, Yar Hussain, Thulanday, Dhobian, Shawe adda, Main bazar, Dhandoqa and Jaganath randomly between March 2015 to September 2015 in sterilized bottles.

\section{Detection of Pathogenic Bacteria}

Samples were inoculated on selective media for pathogenic bacteria including Pseudomonas cetrimide agar (Oxoid) for Pseudomonas aeruginosa, Baird parker agar (Rapid labs, UK) for Staphylococcus aureus and Salmonella /Shigella agar (Oxoid) for Salmonella sp. 100 $\mu \mathrm{l}$ of each sample was inoculated on solid media and spread with the help of sterilized glass spreader. The plates were incubated at $37^{\circ} \mathrm{C}$ for $24-48$ hours in an inverted position.

\section{Analysis of Media for Pathogens}

After 24-48 hours of incubation, the petri dishes were observed for bacteriological enumeration. Salmonella $s p$. was visible as clear, colorless and transparent colonies on Salmonella sp. agar [18,19]. S. aureus was visible as grey colonies. Colonies was presumptively identified as of $P$. aeruginosa when it exhibits a blue-green to green pigment or it may be non-pigmented [20].

\section{Statistical Analysis}

Results were presented in percentages and analyzed statistically by Chi- square test $(\chi 2)$.

\section{Results}

This study has revealed that drinking water can get contaminated with pathogenic bacteria which in human cause infections.

\section{Overall Prevalence of Some Pathogenic Bacteria}

A total of 103 water samples were taken from various areas of district Swabi. The frequency of bacterial contamination in drinking water samples is shown in Table1. Out of 103 water samples 95 (92.23\%) were contaminated with pathogenic bacteria. The highest number of positive samples were contaminated with $S$. aureus with an overall prevalence of $88.34 \%$ (91), followed by Salmonella sp. 68.9\% (71). The lowest prevalence rate was that of $P$. aeruginosa i.e., $24.27 \%$ (25). Statistical analysis revealed significant difference between the prevalence of all the three pathogens $(\mathrm{P}<0.001)$ as shown in Table 1.

\begin{tabular}{|c|c|c|c|}
\hline Types of bacteria & No. of Positive Samples (N=103) & Prevalence (\%) & Chi- Square Test $\left(\boldsymbol{\chi}^{\mathbf{2}}\right)$ \\
\hline Salmonella sp. & 71 & 68.9 & \multirow{2}{*}{$* \mathrm{*}<0.001$} \\
\cline { 1 - 3 } Staphylococcus aureus & 91 & 88.34 & \multirow{2}{*}{} \\
\cline { 1 - 3 } Pseudomonas aeruginosa & 25 & 24.27 & \\
\hline
\end{tabular}

${ }^{*} \mathrm{P}<0.001=$ highly significant.

Table 1: Overall prevalence of Salmonella/Shigella, S. aureus and P. aeruginosa in different water sources of district Swabi. 


\section{Prevalence of Pathogenic Bacteria in Different} Water Sources

Out of 103 water samples 99 were of bore water and 4 samples were of well water. The overall contamination in bore water was $91.9 \%$ (91) and well water $100 \%$ (4) (Table 2). There was no significant difference in overall contamination of different water sources of $(\mathrm{P}>0.05=$ nonsignificant).

\begin{tabular}{|c|c|c|c|c|}
\hline Water Sources & No. of Samples & No. of Positive Samples & Prevalence (\%) & Chi- Square Test $\left(\boldsymbol{\chi}^{\mathbf{2}}\right)$ \\
\hline Bore water & 99 & 91 & $91.90 \%$ & \multirow{2}{*}{$* \mathrm{P}>0.05$} \\
\hline Well water & 4 & 4 & $100 \%$ & \\
\hline Total & 103 & 95 & $92.23 \%$ & \\
\hline
\end{tabular}

*P $>0.05=$ non-significant.

Table 2: Overall contamination of different water sources.

The positive samples of Salmonella $s p$. in bore water were $67.67 \%$ (67). The entire 4 well water samples $100 \%$ were contaminated with Salmonella $s p$. showing overall
$68.9 \%$ (71) contamination (Table 3). There was no significant difference in contamination from all the three sources of drinking water $(\mathrm{P}>0.05=$ non-significant $)$.

\begin{tabular}{|c|c|c|c|c|c|}
\hline Water Sources & No. of Samples & Salmonella sp. & S. aureus & P. aeruginosa & Chi- Square Test $\left(\chi^{2}\right)$ \\
\hline Bore water & 99 & 67.67 & 87.87 & 23.23 & \multirow{2}{*}{$* \mathrm{P}>0.05$} \\
\hline Well water & 4 & 100 & 100 & 50 & \\
\hline Total & $\mathbf{1 0 3}$ & $\mathbf{6 8 . 9 0 \%}$ & $\mathbf{8 8 . 3 4}$ & $\mathbf{2 4 . 2 7}$ & \\
\hline
\end{tabular}

$* \mathrm{P}>0.05=$ non-significant.

Table 3: Prevalence (\%) of Pathogenic bacteria in two water sources.

Presence of S. aureus in bore water was $87.87 \%$ (87), while all 4 well water samples $100 \%$ were also contaminated with this bacteria (Table 4). Overall prevalence of $S$. aureus contamination was $88.34 \%$. There was no significant difference in contamination from all the three sources of drinking water $(\mathrm{P}>0.05=$ nonsignificant).

\begin{tabular}{|c|c|c|c|c|}
\hline Areas (N) $^{\mathbf{a}}$ & S. aureus & P. aeruginosa & Salmonella sp. & Chi- square test $\left(\boldsymbol{\chi}^{\mathbf{2}} \mathbf{~}\right.$ \\
\hline Asmila (19) & 89.47 & 31.5 & 89.47 & \\
\hline Adeena (17) & 100 & 11.7 & 70.8 \\
\hline Yar Hussain (10) & 100 & 10 & 80 \\
\hline Dhobian (10) & 90 & 20 & 63.6 \\
\hline Tulanday (11) & 81.8 & 36.36 & 64.28 \\
\hline Kalo Khan (14) & 78.57 & 42.8 & 80 \\
\hline Jaganath (100 & 90 & 30 & 0 \\
\hline Shawe adda (2) & 50 & 0 & 20 \\
\hline Dhandoka (5) & 60 & 0 & 80 \\
\hline Main bazar (5) & 100 & 20 & $\mathbf{6 8 . 9}$ & \\
\hline Total (103) & $\mathbf{8 8 . 3 4}$ & $\mathbf{2 4 . 2 7}$ & \\
\hline
\end{tabular}

$* \mathrm{P}>0.05=$ non-significant; $\mathrm{Na}=$ No. of samples collected from each area.

Table 4: Prevalence (\%) of pathogenic bacteria at different areas of district Swabi.

Overall contamination with P. aeruginosa was $24.27 \%$. Out of 4 well water samples $2(50 \%)$ were contaminated with $P$. aeruginosa. There was no significant difference in contamination from the sources of drinking water ( $P>0.05=$ non-significant), (Table 3).

\section{Area Wise Prevalence of Pathogenic Bacteria}

Bacterial contamination was variable in different areas (Table 4). The highest prevalence of Salmonella sp. was found in Asmaila i.e $89.47 \%$ followed by Dhobian, Jaganath and Swabi main bazar where the contamination 


\section{International Journal of Zoology and Animal Biology}

was $80 \%$, Kalo Khan, Tulanday and Adeena the contamination was $64.28 \%, 63.6 \%$ and $58.8 \%$, respectively. The lowest contamination was detected in Dhandoka i.e., 20\%. No Salmonella were found in Shawe adda. No significant difference was observed in contamination of drinking water from all areas $(\mathrm{P}>0.05)$.

\section{Area Wise Prevalence of $S$. aureus}

The highest percentage of $S$. aureus was recorded in Adeena, Yar Hussain and Swabi main bazar where the percentage of contamination was $100 \%$. In Jaganath and Dobyan the contamination was $90 \%$ followed by Asmaila, Toolandai, Kalu Khan and Dandoqa where the contamination was $89.47 \%, 81.8 \%, 78.57 \%$ and $60 \%$, respectively. In Shawa adda the contamination was $50 \%$ (Table 4).

\section{Area Wise Prevalence of $P$. aeruginosa}

The highest percentage of contaminated samples with $P$. aeruginosa was recorded in Kalu khan where the percentage of contamination was $42.8 \%$. In Toolanday the contamination was $36.36 \%$ followed by Asmaila, Jaganath, Dobyan, Swabi main bazar, Adeena, Yar Hussain where the contamination was $31.5 \%, 30 \%, 20 \%, 20 \%, 11.7 \%$ and $10 \%$ respectively. No samples were contaminated in Shawe adda and Dandoqa. In shawe adda and Dandoqa the contamination was 0\% (Table 4).

\section{Discussion}

Consuming clean and hygienic water is one of the basic requirements of a society [21]. Pakistan has water supplies adequate only to achieve the drinking requirements of $79 \%$ of its total inhabitants and a chief portion of that water supply is from ground i.e. boring water which they use for drinking [22].

In the present study drinking water samples were analyzed for bacterial contamination from areas of district Swabi, Khyber Pakhtunkhawa Province, Pakistan. The results revealed the total number of positive samples of Salmonella spp. were $68.9 \%, S$. aureus $88.34 \%$ and $P$. aeruginosa were found in $24.27 \%$. This indicating very high contamination of drinking water of swabi and high risk for the diseases caused by these bacteria. Although mostly studies are conducted on presence or absence of coliforms, presence of these pathogens in drinking water was reported from other areas of Pakistan. Ahmad, et al. [23] worked on drinking water quality of District Peshawar (Khyber Pakhtunkhwa Province), Pakistan and reported lesser prevalence of these pathogens. According to him $16.67 \%$ samples were contaminated with
Salmonella typhi, 26.67\% samples with Pseudomonas and $26.67 \%$ samples with Shigella spp. This difference may be due to better sanitary conditions in Peshawer and people are much aware of importance of personal hygiene as compared to Swabi, which is less developed.

Some studies were conducted in Karachi (Sindh Province) which also indicated positive samples of drinking water for P. aeruginosa, S. aureus and Salmonella [23-26]. Another study from Sindh was conducted in Sukkur and reported the prevalence of $P$. aeruginosa in 78\% drinking water samples [27].

Many studies have been conducted in various parts of the world for the bacteriological analysis of drinking water for the presence of pathogenic bacteria. From Iran $P$. aeruginosa separated from the drinking water samples was $2 \%$ [21]. P. aeruginosa was also detected in $6(11.4 \%)$ of the hospital water systems in Tehran, Iran. Masoumi, et al. [28] reported contamination with $P$. aeruginosa as $3.70 \%$ in chlorinated tap water and $20.37 \%$ in water filter system from Shiraz, Iran, respectively.

In Nigeria the contamination of Salmonella typhi, Shigella sonnei and Staphylococci was reported 3.1\%, 5.6\% and $10.8 \%$ respectively in drinking water [29]. Salmonella spp., (44.8\%) and Staphylococcus spp. (37.9\%) were more prevailing in the samples of packaged drinking water sold in Nigeria [30] while from Ahiazu Mbaise, Eastern Nigeria Salmonella spp. and Shigella spp. were 100\% in drinking water sources [31]. Salmonella enterica was also found in $3.3 \%$ of the drinking water resources from Gidan Kwano, Minna, Niger state, Nigeria [32].

From Uttarakhand region of India, S. aureus found dominating species comprising of $68.75 \%$ of the total Staphylococci, while from Andhra Pradesh, India also Salmonella typhi, S. aureus and Shigella dysenteriae were reported $[33,34]$.

In the present study the percentage pathogens were high in well water as compared to contamination in bore water. From Andhra Pradesh, India the percentage of Salmonella typhi, S. aureus and Shigella dysenteriae was $10.6 \%, 19.9 \%$ and $8.2 \%$, respectively, in bore water used for drinking and in well water was $12.40 \%, 19.57 \%$ and $10.65 \%$ respectively [34]. P. aeruginosa was also found in different drinking water resources of Makkah city, Saudi Arabia. Eleven drinkable wells water samples (91.7\%) and all non-drinkable wells water samples (100\%) were contaminated with $P$. aeruginosa [35]. S. aureus also reported from highly developed country of USA. Over $6 \%$ of 320 drinking water samples from Oregon, United States 


\section{International Journal of Zoology and Animal Biology}

were contaminated with this pathogen [36]. The most common source examined was that of well water.

The differences in results of all studies discussed above, may be due to several reasons including geographical differences, scio-economic conditions, types of sample collection method, number of microorganisms which were isolated and type of water samples.

The results of this study exposed that the bacteriological quality of given sources was not satisfactory. The water sources were contaminated with Salmonella sp., P. aeruginosa, S. aureus. It is a serious threat to the people of the area if proper measurements are not taken by the concerned authorities.

\section{References}

1. Prairie Farm Rehabilitation Administration (PFRA) (2003) Agriculture and Agricultural food Canada.

2. Ahmed T, Kanwal R, Tahir SS, Rauf N (2004) Bacteriological analysis of water collected from different dames of Rawalpindi/ Islamabad Region in Pakistan. Pak J Biol Sci 7(5): 662-666.

3. Okonko IO, Ogunjobi AA, Fajobi EA, Onoja BA, Babalola ET, et al. (2008) Comparative studies and microbial risk assessment of different Ready-to-Eat (RTE) frozen sea-foods processed in Ijora-olopa, Lagos State, Nigeria. Afr J Biotechnol 7(16): 408-415.

4. Cunningham WP (2005) Environmental Science: A Global Concern. $8^{\text {th }}$ (Edn.), McGraw-Hill, New York.

5. Onyango DM, Angienda PO (2010) Epidemiology of Waterborne Diarrhoeal Diseases among Children Aged 6-36 Months Old in Busia-Western Kenya. Int J Biol Life Sci 4(1): 38-45.

6. Nollet LML (2000) An Attractive Way of Developing the Concept of Systematic Titration Error of Visual Acid-Base Titrations (on the Basis of Logarithmic Acid-Base Diagrams). Handbook of Water Analysis 2(1): 8-20.

7. Shar AH, Kazi YF, Soomro IH, Zardari M (2009) Bacteriological quality of drinking water of Sukkur city. Pak J Med Res 48(4): 88-90.

8. Holgate G (2000) Water Quality: DETR consultation on new regulations for drinking water. Environmental and Waste Management 3: 105-112.
9. Huang GH, Xia J (2001) Barriers to sustainable water quality management. J Environ Manage 61(1): 1-23.

10. Bartram J, Lewis K, Lenton R, Wright A (2005) Focusing on improved water and sanitation for health. Lancet 365(9461): 810-812.

11. Medema GJ, Payment P, Dufour A (2003) Safe drinking water: an ongoing challenge, In assessing Microbial Safety of Drinking Water, Improving Approaches and Method; WHO \& OECD, IWA publishing, London, UK, pp: 11-45.

12. Anwar MS, Lateef S, Siddiqi GM (2010) Bacteriological quality of drinking water in Lahore. Biomedica 26: 66-69.

13. Hannan A, Shan S, Arshad U (2010) Bacteriological analysis of drinking water of 100 families of Lahore by filtration membrane technique and chromagar, Biomedica 26: 152-156.

14. Aziz JA (2005) Management of source and drinkingwater quality in Pakistan, East Mediterr Health J 11(5-6): 1087-1098.

15. Kahlown MA, Tahir MA, Sheikh AA (2004) Water Quality Status in Pakistan: Second Report 2002- 2003, Pakistan Council of Research in Water Resources, Islamabad.

16. Wright J, Gundry S, Conroy R (2004) Household drinking water in developing countries: a systemic review of microbiological contamination between source and point of use. Trop Med Int Health 9(1): 106-117.

17. Obi CN, Okacha CO (2007) Microbiological and physico-Chemical of selected bore hole waters in world bank housing estate, Umuahia, Abia State, Nigeria. J Eng Applied Sci 2(5): 920-929.

18. Paper read at Microbiological Congress 1950, Pub Health Reports. 65: 1075.

19. (1950) Workers in Pullorum Disease Control Burlington. Meet, Northeastern Conf. Lab., Vermont. Proc $22^{\text {nd }}$ Ann.

20. Brown VI, Lowbury EJL (1965) Use of an Improved Cetrimide Agar Medium and other Culture Methods for Pseudomonas aeruginosa. J Clin Pathol 18(6): 752-756. 


\section{International Journal of Zoology and Animal Biology}

21. Amouei A, Miranzadeh MB, Shahandeh Z, Shahandeh Z, Taheri T, et al. (2012) A study on microbial quality of drinking water in rural areas of Mazandaran province in north of Iran. JEP 3(7): 605-609.

22. Ahmad B, Liaquat M, Ali, Bashir S, Mohammad S, et al. (2014) Microbiology and Evaluation of Antibiotic Resistant Bacterial Profiles of Drinking Water in Peshawar, Khyber Pakhtunkhwa. WASJ 30(11): 16681677.

23. Khatoon A, Pirzada ZA (2010) Bacteriological quality of bottled water brands in Karachi. Pakistan Biologia 56(1\&2): 137-143.

24. Amin S, Abdulla FE, Usman G (2014) Bacterial analysis and antimicrobial susceptibility of bacteria found in different water sources in Karachi. Pak J Med Dent 3: 62-67.

25. Farooqui A, Khan A, Kazmi SU (2009) Investigation of a community outbreak of typhoid fever associated with drinking water. BMC Public Health 9: 476.

26. Yousuf FA, Siddiqui R, Khan NA (2014) Survey of Gram Negative and Gram Positive Bacteria in Drinking Water Supplies in Karachi, Pakistan. Br Microbiol Res J 4(6): 592-597.

27. Shar AH, Kazi YF, Kanhar NA, Soomro IH (2012) Bacterial community patterns of municipal water of Sukkur city in different seasons. Afr J Biotechnol 11(9): 2287-2295.

28. Masoumi JS, Haghkhah M, Mehrabani D, Ghasempour HR, Esmaeelnejad Z, et al. (2013) Quality of Drinking Water of Household Filter Systems in Shiraz, Southern Iran , MEJSR 17(3): 270-274.
29. Taura DW, Hassan A (2013) Bacteriological examination of households drinking water in some local Government areas of Kano state, Nigeria. IRJPP 3(6): 91-96.

30. Odeyemi OA (2015) Bacteriological safety of packaged drinking water sold in Nigeria. Springerplus 4: 642 .

31. Charity EO, Abanobi OC, Emeka IC (2012) Enteric pathogens and diarrhea disease potentials of water sources in Ahiazu Mbaise, Eastern Nigeria. JPHE 4(2): $39-43$.

32. Egbe EO, Mawak JD, Oyewole OA (2013) Microbiological Quality of Water in Fulani Settlements in Gidan Kwano, Minna, Niger State, Nigeria. J Microbiol Res 3(2): 67-70.

33. Sood A, Pandey P, Bisht S, Sharma S (2014) Anthropogenic activities as a source of high prevalence of antibiotic resistant Staphylococcus aureus in the River Ganga. Applied Ecology and Environmental Research 12: 33-48.

34. Laxmi Sowmya K, Sandhya Deepika D, JB Atluri (2013) Quality Assessment of Drinking Water from Kondiba an Agency Area, Andhra Pradesh. RJPBCS 4(3): 190-199.

35. Saati AA, Faidah HS (2013) Environmental Prevalence of Pathogens in Different Drinking Water Resources in Makkah City (Kingdom of Saudi Arabia). Curr World Environ 8(1): 37-53.

36. Lechevallier MW, Seidler RJ (1980) Staphylococcus aureus in Rural Drinking Water. Appl Environ Microbiol 30(4): 739-742. 